\title{
Dispel clouds of pandemic through cooperation
}

\section{Ming Zhang ${ }^{1}$}

Published online: 3 June 2020

C Springer-Verlag GmbH Germany, part of Springer Nature 2020

The start of 2020 saw the outbreak of COVID-19, which has spread globally. This new virus, unknown to mankind, poses a serious threat to life and health. In response to the outbreak, China has adopted the most comprehensive, rigorous and thorough measures to contain the spread of the virus. Assistance in manpower and supplies was rapidly sent to Hubei Province, the city of Wuhan in particular, from across the country. The whole nation has been fighting the virus in solidarity, and managed to bring the situation under control in a relatively short period of time. The achievements would not have been possible but for the enormous sacrifices of the Chinese people, especially those in Wuhan. According to a study published by Science, the containment measures adopted in Wuhan and nationwide in the first 50 days of the outbreak may have prevented more than 700,000 infections, making the number of confirmed cases 96 percent fewer than expected in the absence of interventions. China bought precious time for the rest of the world by building a crucial line of defense.

Since the very beginning, China has provided timely updates on the pandemic in an open, transparent and responsible manner. We shared the virus genome sequence in the shortest possible time, acclaimed by the WHO as record-breaking. We have shared our experience with the WHO and the international community without any reservation, and provided assistance in the best way we could. We have held more than 80 video conferences with health experts from more than 150 countries, and sent 19 medical teams to 17 countries. The Chinese government and private sectors have or are providing much-needed medical supplies to more than 150 countries and international organizations.

A virus respects no borders nor distinguishes between races. The pandemic underscores the fact that the destinies of all countries are intertwined in the era of globalization. At this critical moment, China and the EU have chosen to work together to meet the challenges, setting a good example of cooperation and solidarity. When China was at a most difficult time in fighting the outbreak, the EU facilitated the delivery of over

Ming Zhang is Ambassador Extraordinary and Plenipotentiary and Head of the Chinese Mission to the EU.

Ming Zhang

chinamission_eu@mfa.gov.cn

1 Mission of the People's Republic of China to the European Union, Brussels, Belgium 
50 tons of medical supplies in three batches from its member states. Such a sign of friendship will always be remembered and cherished by the Chinese people. When the pandemic hit Europe, China, despite its own difficulties at home, sent masks, testing kits and other essential medical supplies to the EU. Chinese governments at various levels, charitable organizations, businesses, chambers of commerce and citizens are extending a helping hand to Europe, and some are assisting European companies in purchasing much-needed supplies from China.

Chinese assistance is a humanitarian action. We do not stand idly by while our friends are out there in difficulties. We have no interest to "compete" with anyone, but are doing our best to help. Our wish is simple. We hope our experience could be useful in helping other countries fight the pandemic and save as many lives as possible.

As the WHO pointed out, we are fighting both the pandemic and the "infodemic". Disinformation is an enemy to all nations, and China is a victim. Some countries and individuals are resorting to stigma and labeling, inciting racial and national discrimination and poisoning the atmosphere of international cooperation. Such disinformation does no good to the global fight against the pandemic and should be flatly rejected by the whole international community.

It is encouraging to note that European countries are working together, and that the situation in some countries is improving. Mr. Jean Monnet, a founding father of the EU, said that Europe will be forged in crises. It is our firm conviction that Europe will emerge stronger and more united from the current crisis. As stated on many occasions, China is happy to see a united, stable, open and prosperous Europe, and China firmly supports the European integration process, supports a united and strong EU, and supports a more active role of Europe in international affairs. This is China's longstanding policy towards Europe and will not change due to the outbreak.

The full impact of the pandemic is yet to be felt. As the world's two staunch forces for stability and major economies, China and the EU have a joint responsibility to promote world prosperity and stability, uphold multilateralism and an open world economy, and strengthen international cooperation. Building on what we have already done together, the two sides need to make further efforts to contain the spread of the virus and contribute to a speedy global recovery.

First, we need to lead the global cooperation on COVID-19. China and the EU need to enhance information-sharing and explore the possibility of establishing a coordinated response mechanism. The two sides could draw on each other's strengths, encourage companies and research institutes to engage in cooperation on pharmaceutical and vaccine development to make the world more capable and confident of defeating the pandemic.

Second, we need to uphold multilateralism. As practitioners of multilateralism, China and the EU should support the WHO in playing its due role in the global cooperation on COVID-19, uphold the status and role of the United Nations, and contribute to a coordinated global response, thus lending a strong impetus to the global fight against the pandemic.

Third, we need to increase support for vulnerable regions. Active efforts should be made to develop joint projects for helping Africa and other developing countries improve their public health systems and enhance their capacity in response to COVID-19. The two sides should step up communication and coordination and work together to address regional and international hotspot and sensitive issues as well as global challenges such as food crisis. 
Fourth, we need to strengthen macro policy coordination. Within the framework of G20 and other mechanisms, China and the EU should leverage and coordinate their macro policies to mitigate the negative impact brought by the pandemic on global economy. The two sides should jointly keep global industrial and supply chains stable and promote trade and investment liberalization and facilitation, contributing to more inclusive and sustainable development.

The world is almost on pause because of COVID-19. This year's China-EU agenda has also been affected to some degree. Yet the two sides have maintained close communication. Chinese and EU leaders stay in touch by telephone and correspondence. The closely watched negotiations on the China-EU investment agreement have been held as scheduled through video conferencing. Trials and tribulations will only make us stronger. I am convinced that cooperation is like sunshine. It will help dispel the dark clouds of the pandemic and usher in a brighter future for China-EU relations.

Publisher's note Springer Nature remains neutral with regard to jurisdictional claims in published maps and institutional affiliations. 